\title{
地域高齢者における閉じこもりとライフスタイルとの関連 \\ The relation of Lifestyle with homebound in community elderly residents
}

\author{
宮原洋八
}

HIROYA MiYABARA

\begin{abstract}
要旨 : 目的 : 閉じこもり高齢者に影響を及ぼす要因とライフスタイルのカットオフ值を求 めることを目的とした。方法 : 2007年 A 市保健センターにおいて健康診断を受けた60歳 以上の住民のうち, 男女211名を対象に, 閉じこもり, ライフスタイル, 生活機能, 主観 的健康感に関する質問紙による調査を行った。結果 : 閉じこもりと年齢，ライフスタイル， 生活機能, 主観的健康感が閉じこもりの有無と有意に関連しており，ROC 分析では, 閉 じこもりの AUC (area under the curve) は高い値を示した $(088)$ 。結論 : 地域で閉じこも り予防活動等を行う際には，高齢者のライフスタイル，生活機能に着目した活動内容を援 助することにおいて有効であることが示唆された。
\end{abstract}

キーワード : 地域高齢者, 閉じこもり予防，ライフスタイル, 生活機能

\begin{abstract}
Aim: The purpose of the study was to examine the characteristics of homebound in the community elderly residents and cut-off values in lifestyle.

Methods: Lifestyle was evaluated with the health assessment survey in ACity in 2007 that contains questionnaire entries of problematic behavior in elderly: homebound (shutting oneself in his/her room or house), lifestyle, life function, self-rated health. The subjects of the survey were 211 residents.

Results: We examined the relationship between homebound and each problem behavior. Relationships of homebound with age, lifestyle, life function, self-rated health were statistically significant. In the ROC analysis, AUC (area under the curve) of lifestyle in homebound showed high score 0.88 . Conclusion: When performing prevention activities for the homebound in communities, it was suggested that it is an effective to examine the contents of social lifestyle, life function.
\end{abstract}

Key words: Community elderly residents, Prevention of homebound, lifestyle, life function

\footnotetext{
受付日：2012年 3 月19日 , 採択日 : 2012年 4 月27日

西九州大学リハビリテーション学部

T 8428585 佐賀県神埼市神埼町尾崎4940 1

Department of Rehabilitation Sciences, Nishikyushu University: 4490-9 Ozaki, Kanzaki, Saga, 842-8585, Japan. Tel+81-952-52-4191
} 
I .はじめに

厚生労働省は介護予防の観点から，2000年に創設さ れた「介護予防・生活支援事業」の一環として閉じこ もり予防を取り上げた ${ }^{1}$ 。近年, 地域高齢者の閉じこ もりに関する研究が高い関心を集めるようになってき た ${ }^{2-4)}$ 。しかし，閉じこもりの定義はいまだに統一が なされておらず, 移動能力を基準としたものや, 生活 行動の範囲から複合的に定義したもの，閉じこもりと いう概念を用いていないか障害老人の日常生活自立度 から検討したものなど, 各研究において定義や少の判 断基準も異なっている ${ }^{3.5}$ 。こうした中，現場では使用 しやすい指標として，外出頻度を用いた閉じこもりに 関する研究が見受けられるようになった6。

一方, 老年学の分野でサクセスフル・エイジング (Successful Aging) の用語が用いられるようになった が $^{8)}$ ，これは高齢期の自立や生きがい，満足感を含む 概念であり高齢社会においては大いに望まれている。 サクセスフル・エイジングは健康日本21政策の到達目 標であることから，ライフスタイルが高齢者保健福祉 施策の目指すべき具体的指標として不自然でないと指 摘し, 高齢社会での健康増進活動において介入し, 手 法を開発していくためには，高齢期の健康を「自立生 活を保障する活動能力や健康感・幸福感などの精神的 自立」と定義 ${ }^{910)} し$ ，このような健康の維持・向上に 寄与すると思われるライフスタイルを身体（健康増進 のための行動)，心理 (心の安寧をもたらす行動) , 社 会 (社会参加に関する行動) の3 側面から幅広くとら え検討していくことが重要であると指摘している。

今後, 超高齢社会での健康増進活動において介入し， 手法を開発していくために芳賀6,7) は, サクセスフル エイジングは健康日本21政策の到達目標であることか ら，ライフスタイルが高齢者保健福祉施策の目指すべ き具体的指標として不自然でないと指摘している。こ れまで, ライフスタイルと健康の関連が検討8 ${ }^{89}$ されて きたが, 弚こで取り上げられたライフスタイル要因は Breslow $^{10}$ らの研究に代表される健康習慣を問うもの であった。

先行研究では, 芳賀9が, ライフスタイル42項目に ついてプレテストを行い, 光の妥当性や信頼性を検討 した結果22項目まで絞り込んだ質問表を奄美の風土に 合うように1部改変して用いたこと（改変した質問表 の妥当性や信頼性も検討済み $\left.{ }^{111}\right)$, 光のライフスタイ 儿質問項目と運動能力, 生活機能, 要介護度, 身体疾 患の有無などの要因の関連を調査し , ライフスタイル
が良好な者は運動能力, 生活機能も良好で, ライフス タイルが不良な者は要介護状態の者に多いという仮説 を実証した

これまで地域高齢者における ADL (Activities of daily Living; ADL) 低下の予防には，「良好な食生活」,「週 $2 \sim 3$ 回の外出」, 「高学歴」, 「友達との交流頻度が高 い」などが追跡調査 ${ }^{13}{ }^{14}$ により確認されている。しか しながら，閉じこもりと身体，心理，社会の3 側面か らなるライフスタイル質問項目との関連は明らかにさ れておらず，またライフスタイル得点がどの程度必要 であるかは不明のままである。

弚こで本研究では, 閉じこもりをほとんど外出しな い( 1 週間に 1 回以下) とし ${ }^{6)}$, 閉じこもり高齢者に 影響を及ぼす要因とライフスタイルのカットオフ値を 求めることを目的とした。

\section{II. 方 法}

1. 対 象

対象者は，2007年にA市保健センターにおいて健 康診断を受けた60歳以上の住民211人である (表 1 )。 対象者には, 調査趣旨, 調査への参加は強制ではない こと，調査により取得されたデータは研究以外の目的 で使用しないこと，またデータは匿名化され使用され ることを口頭で説明し，対象者からインフォームドコ ンセントを得た。

\begin{tabular}{|c|c|c|c|}
\hline & 男 & 女 & 計( \%) \\
\hline 60～74歳 & 29 & 54 & $83(39)$ \\
\hline 75～90歳 & 36 & 92 & $128(61)$ \\
\hline 計( \% ) & $65(31)$ & $146(69)$ & $211(100)$ \\
\hline
\end{tabular}

\section{2 . 調査項目}

調査項目は, 性, 年齢, 外出頻度 (週 2 回以上/週 1 回以下), 主観的健康感(健康である/健康でない) を質問紙にて聴取した。ライフスタイルに関する質問 は，芳賀ら ${ }^{13}$ により作成された22項目（社会的健康に 関する8 項目，心理的健康に関する 6 項目，身体的健 康に関する8項目)を用いたが, 光のうちの 1，9，16，22の項目は奄美の風習に合うように改变 し表 2 に示した。芳賀ら ${ }^{15}$ の質問項目 (以下：原本) 1では「自治体，村内会の催しや行事」とあるが，奄 美では集落主催の行事として，旧暦4月に家族で海浜 に行き弁当を食べる浜下れ（はまおれ），旧暦8月に 
表 2 ライフスタイル

\begin{tabular}{|c|c|}
\hline $\begin{array}{l}\text { 質問項目 } \\
\end{array}$ & 尺度 \\
\hline $\begin{array}{l}\text { 1行事 (浜下れ，八月踊り，種おろしなど）はかか } \\
\text { さず行きますか }\end{array}$ & \\
\hline 2 美化活動 (河川, 浜) に参加していますか & \\
\hline 3 集落内の世話役を何かしていますか & 社 \\
\hline 4 趣味がありますか & 会 \\
\hline 5ボランティアに参加しますか & 的 \\
\hline 6 近所づきあいをしますか & \\
\hline 7 老人クラブに参加しますか & \\
\hline 8仕事 (家事，はたおり，畑など) をしていますか & \\
\hline 9 墓参りにはかかさずいきますか & \\
\hline 10くよくよしないようにしていますか & 心 \\
\hline 11何か挑戦することがありますか & 玾 \\
\hline 12明るく考えるようにしていますか & 理 \\
\hline 13夢や目標がありますか & 的 \\
\hline 14いらいらしないようにしていますか & \\
\hline 15草取りなどの作業をよくしますか & \\
\hline 16お茶請けにみ乥をひかえますか & \\
\hline 17散歩や体操をしていますか & 身 \\
\hline 18早寝早起きをこころがけていますか & 休 \\
\hline 19肉類を食べると脂身をひかえますか & \\
\hline 20健康診断を受けていますか & 的 \\
\hline 21ゲートボールや他のスポーツをしてい & \\
\hline 22黑砂糖をひかえますか & \\
\hline
\end{tabular}

豊年祭，旧暦 9 月に五穀豊穣を祈願する種下し（たね おろし) がある。このため，質問項目 1 を「行事（浜 下れ，八月踊り，種下しなど)はかかさず行きますか」 とし，原本 9 は「仏神事に熱心である」とあるが，奄 美では本土の樣な仏閣がなく先祖崇拝に熱心で毎月旧 暦の1日と15日には墓参りに行く。このため, 質問項 目 9 を「墓参りにはかかさず行きますか」とし，原本 16は「塩分を取り過ぎない」とあるが，奄美ではお茶 受けに落花生や塩づけの豚肉を入れた粒状の味噌をよ く食べる。このため，質問項目16を「お茶受けにみ光 をひかえますか」とし，原本22は「間食をひかえる」 とあるが，奄美では間食に菓子よりも黑砂糖をよく食 べる。このため，質問項目22を「黑砂糖をひかえます か」とした。生活機能の測定には老研式活動能力指標 (以下 : 老研式指標) を用いた ${ }^{14)}$ 。ライフスタイル項 目および老研式指標は，いずれも2 件法（０と１）で 回答するようになっているので, 得点の分布は前者で は 0 22点, 後者では $0 〜 13$ 点である。

\section{3. データの分析方法}

まず外出頻度で, 週 2 回以上の外出があれば (非閉 じこもり群), 週 1 回以下の外出であれば (閉じこも り群) とした。乥して产の2 群と年齢, 性, ライフス

表 3 閉じこもり群と非閉じこもり群の比較

\begin{tabular}{|c|c|c|c|c|}
\hline & & $\begin{array}{c}\text { 閉じこもり群 } \\
(\mathrm{n}=28)\end{array}$ & $\begin{array}{c}\text { 非閉じこもり群 } \\
(\mathrm{n}=183)\end{array}$ & \\
\hline \multicolumn{5}{|l|}{$\chi^{2}$ 検定を用いた項目 } \\
\hline \multirow[t]{2}{*}{ 性別 (人数) } & 男性 & 11 & 54 & $\chi^{2}=213.0$ \\
\hline & 女性 & 17 & 129 & $\mathrm{p}<0.001$ \\
\hline \multirow[t]{2}{*}{ 主観的健康感 (人数) } & 健康である & 6 & 137 & $\chi^{2}=2438$ \\
\hline & 健康でない & 12 & 46 & $\mathrm{p}<0.001$ \\
\hline
\end{tabular}

$\mathrm{t}$ 検定を用いた項目

年齢

社会的ライフスタイル 心理的ライフスタイル 身体的ライフスタイル ライフスタイル指標合計 手段的自立 知的活動性 社会的役割 生活機能指標合計

\begin{tabular}{|c|c|}
\hline (歳) & $82.4(7.4)$ \\
\hline (点) & 12 (1.7) \\
\hline (点) & $18(13)$ \\
\hline (点) & 3.0 (2 1) \\
\hline (点) & $61(45)$ \\
\hline (点) & $08(1.4)$ \\
\hline (点) & $12(0.9)$ \\
\hline (点) & 1.0 (1 1) \\
\hline (点) & $31(2.7)$ \\
\hline
\end{tabular}

\begin{tabular}{|c|c|}
\hline $75.5(8.4)$ & $* * *$ \\
\hline $58(18)$ & $* * *$ \\
\hline $42(15)$ & $* * *$ \\
\hline $5.9(16)$ & $* * *$ \\
\hline $16.0(42)$ & $* * *$ \\
\hline $4.4(12)$ & $* * *$ \\
\hline $32(0.9)$ & $* * *$ \\
\hline $35(0.9)$ & $* * *$ \\
\hline $111(2.6)$ & $* *$ \\
\hline
\end{tabular}


タイル, 生活機能, 主観的健康感を比較するために $\mathrm{t}$, $\chi^{2}$ 検定を用いて調べた。次に，状態変数に閉じこもり， 非閉じこもりを投入し，検定変数にはライフスタイル 得点を投入し, Receiver Operating Characteristic(ROC) 曲線を描いた。ROC 曲線の検討では，閉じこもり， 非閉じこもりを判断するカットオフ值を決定し，感度， 特異度，正診率を算出した。なお，判別性能を ROC 曲線で描写した曲線下の面積 AUC (area under the curve) で求めた。統計解析にはSPSS18 .0を用い，統 計的検定の有意水準はいずれも 5 \%未満とした。

\section{III. 結 果}

「閉じこもり群」,「非閉じこもり群」と各測定項目 間の比較では, 年齢は「非閉じこもり群」が，「閉じ こもり群」より有意に低く $(\mathrm{p}<0.001)$, ライフスタ イル (3 尺度, 合計得点), 生活機能 (3 尺度, 合計 得点）においては「非閉じこもり群」が，「閉じこも り群」より有意に高かった $(\mathrm{p}<0.001)$ 。主観的健康 感は「非閉じこもり群」が，「閉じこもり群」より健 康である割合が有意に高かった $\left(\chi^{2}=2438, \mathrm{p}<\right.$ 0 .001)(表 3 )。

ROC の解析結果では，AUC が最も大きく，有意水 準を満たしたものは, 閉じこもりにおけるライフスタ イルの值が10 5点（漸近有意確率0 .000, 95\%CI： 0812 - 0 949) であった。カットオフ值の感度は93\%， 特異度は $25 \%$ であり，正診率は93\%と良好であった。 なおAUC は0 880であった (図 1 )。

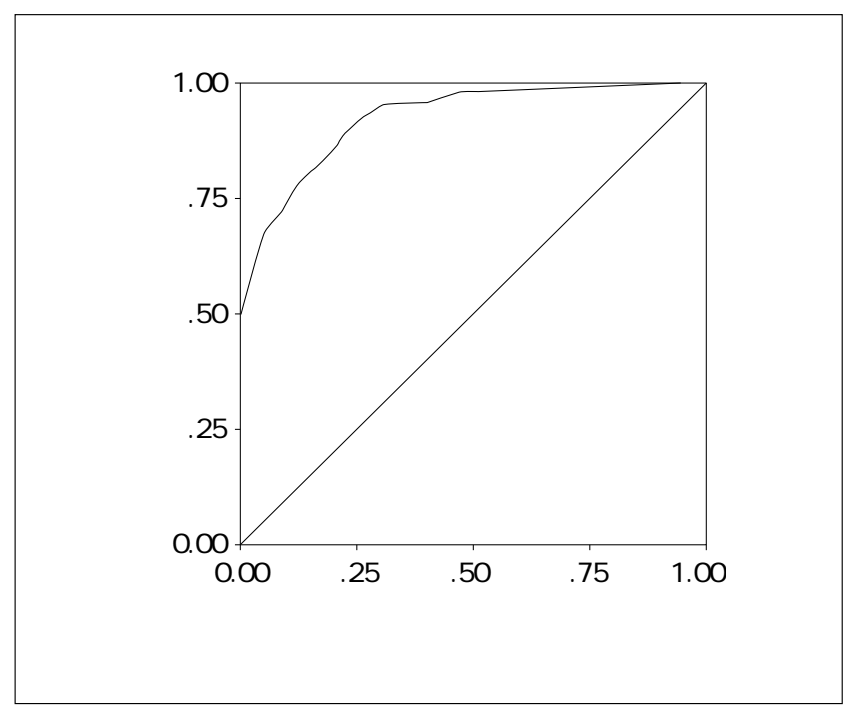

图 1 外出頻度を判別するライフスタイル得点の ROC 曲線 カットオフ值 $=10.5$ 点, 漸近有意確率 $=0.000$, 感度 $=93 \%$, 特異 度 $=25 \%, \mathrm{AUC}=0880$, 正診率 $=93 \%$

\section{IV. 考 察}

高齢化社会に伴う今日の保健医療の領域において， 寿命の延長から活動能力を維持した健康寿命の延長を 目標とするのであれば，高齢者の活動自立の維持に有 効なライフスタイル要因を探索し検証しなければなら ない。㫕の要因の1つに閉じこもりなどが選ばれてい

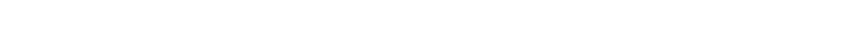
健康度自己評価が低く，転倒恐怖感が高く，生活機能 が低く，身体機能が低いことが指摘されている ${ }^{18)}$ 。閉 じこもりは生活機能と関連しながら寝たきりに移行し やすい危険因子であることは明らかである。光のため， 閉じこもり予防に対するアプローチは，横断的にスク リーニングした各問題行動のうち特に外出頻度が少な い者に対する寝たきり予防や支援が必要である。关こ で本研究では, 高齢者の自立を多元的にとらえるため に作成されたライフスタイル年皇用いて，閉じこもり の判別を行った。弚の結果，閉じこもりを判定するカッ 卜オフ值はライフスタイルで10 5点であった。また ROC 曲線から求めた AUC (0 880) から, Moderate accuracy (AUC : 0 9〜0.7) の予測值があると判断でき た。正診率も93\%であることから，ライフスタイルは， 高い精度で閉じこもりの危険性を判別することが可能 であると推察された。

高齢者は自宅に閉じこもることにより，身体，心理， 社会的な活動能力は低下し，寝たきりとなる可能性が 高くなる ${ }^{18)}$ 。宮原 ${ }^{11}$ は, ライフスタイルの基準関連妥 当性を検証するために，主観的健康感の有無を外的基 準として 1 元配置分散分析を行った結果，健康でない 群のライフスタイルは10 .6点と報告している。このよ うなことから高齢者の閉じこもり予防には，身体・心 理・社会の 3 側面から幅広くとられたライフスタイル を検討していくことが重要であることが示唆された。

芳賀201は，沖縄県 $\mathrm{N}$ 村在住の高齢者のライフスタイ ルに関する追跡調査で, 生活機能, 健康感の縦断的変 化とライフスタイルの変化との関連を分析した結果， ライフスタイルの低下群は, 維持群に比べて, 生活機 能 , 健康感の低下が大きいことを示したと報告してい る。藺牟田 ${ }^{21}$ は, 閉じこもり群と非閉じこもり群の間 における移動介助・食事介助・入浴介助・着衣介助な どの ADL に関する項目や家事・読書・知人とのつき あいなどの社会的項目での有意な関連性や，この 2 群 間での老研式指標の平均点の有意差を指摘している。 本研究でも閉じこもりの要因として身体・心理・社会 の3 側面か関与するライフスタイルや手段的自立・知 
的活動性・社会的役割の老研式指標か関与した。これ らの指標は高齢者の閉じこもり予防を目的とした評価 の可能性が推察された。

WHO 憲章によれば，健康概念とは身体的・精神 的・社会的要素を包括する多元的概念である。志水 ${ }^{22}$ は，山形県 S 市に在住する40歳以上の住民208人を対 象に, 主観的健康感に関連する要因を明らかにし，主 観的健康感は加齢に伴い, 精神的・社会的要因の影響 を強く受けることを報告している。Atchley ${ }^{23}$ は, 壮年 期のライフスタイルのあり方が，弚の延長線上にある 高齡期のライフスタイルに継承され，サクセスフル エイジングのあり方に規定すると指摘している。

本研究から，閉じこもりに関連する項目としてライ フスタイル, 生活機能, 主観的健康感が選択されたこ とは，概ね Atchley らの所説を支持するものである。 ただし, 本研究は男性の割合が少なかっことから男性 のサンプルを増やし男女別に閉じこもりのカットオフ 值を検討することか課題である。今後は追跡調査によ り自立の維持に関連するライフスタイルの各因子につ いて検討し，高齢者の健康増進施策に活かしていきた い。

本論文を終えるにあたり，調査にご協力いただいた 笠利の住民ならびにスタッフの皆さんに深く感謝いた します。

\section{文献}

1) 厚生統計協会編：老人保健，厚生の指標（臨時増刊），国 民衛生の動向 . $2003,50: 105112$.

2 ) 藺牟田洋美, 安村誠司, 藤田正美・他 : 地域高齡者におけ る「閉じこもり」の有病率ならびに身体・心理・社会的特 徵と移動能力の变化. 日本公衛誌, $1998,45(9): 883892$

$3)$ 河野あゆみ : 在宅障害老人における「閉じこもり」と「閉 じこめられ」の特徴 . 日本公衛誌, $2000,47(3): 216229$.

4 ) 鳩野洋子, 田中久恵, 古川馨子 - 他 : 地域高齢者の閉じこ もりの状況と光の背景因子の变分析. 日本地域看護学会 誌, 2001,3 (1) : 26 31 .

5 ) 藺牟田洋美, 安村誠司, 阿部忠之・他 : 自立および準寝た きり高龄者の自立度の变化に影響する予測因子の解明 . 日 本公衛誌, $2002,49(6): 483496$.

6 ) 久保昌昭，横山正博 : 在宅高齡者の閉じこもりに関連する 要因.社会福祉学, $2006,46(3): 3847$.

7 ) Rowe JW, Kahn RL: Human Aging; Usual Successful. Science, 1987; 10(237): 143-149.

8 ) Strawbridge WJ, Cohen RD, Shema SJ: Successful Aging; Predictors and Associated Activities. American Journal of Epidemiology, 1996; 144: 135-141.

9 ) 芳賀博 : 高齢者の心身の健康に及ぼすライフスタイルの影
響。笹川医学医療研究財団, 1996, 12(1) : 117- 121 .

10）芳賀博：在宅の後期高齡者に対する介入プログラムが体力 及び QOL に及ぼす影響. 厚生労働科学研究費補助金 (長 寿科学総合研究事業) 分担研究報告書, 2002:10 17 .

11) 宮原洋八，小田利勝 : 地域高齢者におけるライフスタイル の測定 . 鹿児島県リハビリテーション医学誌 , 2007；18 (1) : 7-10 .

12）宮原洋八，小田利勝 : 地域高齡者のライフスタイルと運動 能力, 生活機能, 社会的属性間との関連. 理学療法科 学, 2007; 22(3) : 397-402.

13）隅田好美, 黑田研二 : 高齡者における日常生活自立度低下 の予防に関する研究 (第一報) . 厚生の指標, 2002；8： 8-13.

14）芳賀博 : 地域在宅高齢者のサクセスフル・エイジングに関 する縦断的研究. 厚生労働科学費補助金 (長寿科学総合研 究事業) 分担研究報告書, 2003: 11- 18 .

15）芳賀博, 安村誠司，鈴木隆雄・他：農村における老人の活 動的自立の維持とライフスタイルとの関連 .民族衛 生, $2001,67: 6876$.

16) 古谷野亘, 柴田博, 中里克治, 他, 地域老人における活動 能力の測定 . 日本公衛誌, 1987, 34(3) : 109114 .

17）崎原盛造：長寿地域高齢者の ADL の加龄変化と心理社会 的要因との関連 . 厚生労働科学研究費補助金 (長寿科学総 合研究事業) 分担研究報告書, 2002, 33 44.

18）宮原洋八，小田利勝 : 地域高龄者の自立とライフスタイル との関連 . 理学療法科学, $2008 ; 23(1): 8589$.

19）藤田幸司，藤原佳典，熊谷修 - 他 : 地域在宅高齢者の外出 頻度別にみた身体·心理·社会的特徵.日本公衛誌, 2004,51 (3) : 168180 .

20）芳賀博 : 地域在宅高齢者のライフスタイルに関する縦断的 研究. 厚生省科学費補助金分担研究報告書, 2001; 18 25.

21) 藺牟田洋美, 安村誠司, 藤田雅美・他 : 在宅高齢者におけ る「閉じこもり」の有病率ならびに身体・心理・社会的特 徵と移動能力の変化 . 日本公衛誌, 1998; 49(9) : 883891 .

22）志水幸, 小関久恵, 嘉村藍: 島嶼地域住民の主観的健康感 の関連要因に関する研究 . 厚生の指標, $2006 ; 53(13): 14$ -19 .

23) AtchleyRC: A continuity Theory of Normal Aging. The Gerontologist, 1989; 29: 183-190. 